\title{
Aluminum toxicity effect on the initial growth of yacon plantlets ${ }^{1}$
}

\author{
Tiago Pacheco Mendes ${ }^{2 *}$, Fábio Luiz de Oliveira ${ }^{2}$, Marcelo Antonio Tomaz ${ }^{2}$, \\ Wagner Nunes Rodrigues ${ }^{2}$, Ariany das Graças Teixeira ${ }^{2}$
}

10.1590/0034-737X201865020002

\begin{abstract}
The increasing consumption of yacon potato has raised worldwide interest in its crop and generated demand for scientific elucidations of several factors associated to its agricultural management. Among the demands, there are the studies related to the effects of aluminum $\left(\mathrm{Al}^{3+}\right)$ on the development of yacon plants. Thus, this study was developed to evaluate the effects of aluminum on budding and initial growth of yacon plantlets. The experiment was carried out in a completely randomized block design, with three replications and six aluminum contents in the substrate: $0,10,25$, 50,100 , and $200 \mathrm{mg} \mathrm{L}^{-1}$. The response of yacon plantlets to aluminum contents was evaluated by the emergence time, emergence speed index, number of leaves, plant height, leaf area, radicle length, and dry mass weight of leaves, stems, and radicles. The presence of aluminum in the substrate negatively influences the emergence and initial growth of yacon, causing losses in foliage development (number of leaves and leaf area), in biomass accumulation, growth and, especially, restricting the development of radicles. Aluminum toxicity fully inhibits radicle growth in substrate contents above $83 \mathrm{mg} \mathrm{L}^{-1}$, under the controlled conditions used in this experiment.
\end{abstract}

Keywords: Smallanthus sonchifolius; Polymnia sonchifolia; diet potato; growth; toxicity.

\section{RESUMO}

\section{Toxidez por alumínio sobre o desenvolvimento inicial de plântulas de yacon}

$\mathrm{O}$ crescente consumo de batata yacon tem despertado interesse mundial pela cultura, o que tem gerado demanda por elucidações científicas de diversos fatores associados ao seu manejo agrícola. Entre as demandas, estão os estudos realacionados aos efeitos efeitos do alumínio $\left(\mathrm{Al}^{3+}\right)$ sobre o desenvolvimento de plantas yacon. Assim, este estudo foi desenvolvido para avaliar os efeitos do alumínio sobre a brotação e o crescimento inicial de mudas de yacon. O experimento foi realizado em delineamento inteiramente casualizado, com três repetições e seis teores de de alumínio no substrato: 0, 10, 25, 50,100 e $200 \mathrm{mg} \mathrm{L}-1$. O comportamento das plântulas de yacon foi avaliado pelo tempo e índice de velocidade de emergência, número de folhas, altura, área foliar, comprimento da radícula e massa seca de folhas, hastes e radículas. A presença de alumínio no substrato influencia negativamente a emergência e o crescimento inicial da yacon, causando redução no desenvolvimento foliar (número de folhas e área foliar), no acúmulo de biomassa, crescimento e restringindo, especialmente, o desenvolvimento da radícula. A toxicidade do alumínio inibe completamente o crescimento radicular em concentrações acima de $83 \mathrm{mg} \mathrm{L}^{-1}$, nas condições controladas usadas neste experimento.

Palavras-chave: Smallanthus sonchifolius; Polymnia sonchifolia; batata diet; toxicidade; crescimento.

\footnotetext{
Submitted on April 12 $2^{\text {th }}, 2017$ and accepted on February 02 $2^{\text {nd }}, 2018$.

${ }^{1}$ This work is part of the first author's course work.

${ }^{2}$ Universidade Federal do Espírito Santo, Centro de Ciências Agrárias e Engenharias, Departamento de Agronomia, Alegre, Espírito Santo, Brazil. tiagopm931@hotmail.com; fabiocapi@yahoo.com.br; tomazamarcelo@yahoo.com.br; wagnernunes86@hotmail.com; arianyteixeira@yahoo.com.br

*Corresponding author: tiagopm931@ hotmail.com
} 


\section{INTRODUCTION}

Yacon potato (Smallanthus sonchifolius) is a species originated from the Andean region and is currently consumed in several other parts of the world, such as North America, Asia, and Europe (Cardoso, 2008). The diffusion of yacon consumption is related to its recognition as functional food (Gusso et al., 2015), due to the presence of bioactive elements in its composition, such as inulintype fructans and fructooligosaccharides (FOS) (Ojansivu et al., 2011).

Several studies have reported the benefits of yacon to human health, for its prebiotic (Campos et al., 2012) and protector effects against colon cancer (Moura et al., 2012), as well as its a role in intestinal functioning (Albuquerque \& Rolim, 2012), immunostimulation (Vaz-Tostes et al., 2014), reduction of serum lipids (Habib et al., 2015), and modulation of fasting insulinemia (Genta et al., 2009). It also has effects on the control of chronic diseases associated with diabetes (Oliveira et al., 2013).

These results have stimulated the consumption of yacon potato, which raised worldwide interest in its crop and generated demand for scientific elucidations of several factors associated to its recent agricultural management (Gusso et al., 2015).

Among the demands, there are studies related to aluminum $\left(\mathrm{Al}^{3+}\right)$ effects on the development of yacon plants. The $\mathrm{Al}^{3+}$ is a metal ion that negatively affects the absorption, transport and, use of essential elements such as $\mathrm{Ca}^{2+}$ and $\mathrm{Mg}^{2+}$ (Freitas et al., 2006), compromising the acquisition, nutrition, and circulation of water in the plants and, consequently, causing serious damage to plant development (Silva et al., 2013).

Aluminum toxicity is one of the most limiting factors to plant growth in acid soils and occurs mainly in soils with $\mathrm{pH}$ below 5 . This problem becomes more common in soils of tropical and subtropical regions, which tend to be more acidic, due to the large precipitation indexes that leach considerable amounts of exchangeable bases (such as magnesium, calcium, sodium, and potassium); the scarcity of primary and secondary minerals, which are responsible for maintaining these bases; and also the edaphic nature of the source material (Marin et al., 2004).

Among the several problems caused by the presence of aluminum in the soil in plant development, the reduction of root growth is the first and most evident symptom (Chandran et al., 2008). Injuries are caused specifically at the root apex, causing impairment of normal root development, reducing or even inhibiting the growth of the root system (Kollmeier et al., 2000). Plants with underdeveloped root systems are, consequently, less vigorous, presenting several secondary limitations and vulnerabilities, and are unable to sustain yields at commercial levels.

Scientific information about the influence of aluminum on the performance of yacon is scarce, lacking quantitative studies that might help to establish the level of tolerance, or sensibility, to aluminum contents, and to measure the economic damage caused by the presence of aluminum in the soil. These studies are especially important for tropical and subtropical regions, where the presence of aluminum is common in soils, which tend to be naturally more acidic. Thus, this study was developed to evaluate the effects of aluminum on sprouting and initial growth of yacon plantlets.

\section{MATERIAL AND METHODS}

\section{Experimental design}

The experiment was carried out at the Laboratory of Plant Physiology and Mineral Nutrition, in the Departamento de Agronomia (Department of Agronomy), in Centro de Ciências Agrárias da Universidade Federal do Espírito Santo, Brazil, from February 04 to March 12, 2016.

The experiment was performed in a completely randomized block design, with three replications and six increasing aluminum contents in the substrate. Each experimental plot consisted of one plastic pot filled with 1 $\mathrm{kg}$ of substrate, which consisted of dried quartz sand previously washed in running water until total removal of impurities, subsequently washed three times with deionized water, and treated to receive yacon rhizophores.

The aluminum contents in the substrate were established by the initial addition of aluminum in the nutrient solution used for fertigation, which was prepared based on a modified Hoagland solution (Hoagland \& Arnon, 1950). Since there is a lack of information about the effect of aluminum on the germination of yacon rhizophores, the aluminum concentrations were established based on preliminary samples and set as 0 , 10, 25, 50, 100, and $200 \mathrm{mg} \mathrm{L}^{-1}$.

Complete nutritional solutions were modified by the addition of $\mathrm{Al}_{2}\left(\mathrm{SO}_{4}\right)_{3}$ in different levels to constitute the treatments, which were applied to the substrate using a standardized volume $(300 \mathrm{~mL})$, necessary to completely moisten the substrate in the ideal amount for sprouting of the rhizophores.

\section{Plant material and incubation}

The yacon rhizophores were previously selected, standardized in size and weight, washed with deionized water, and placed to sprout (three per container) in plastic pots containing the prepared substrate of dried fine sand (Asp et al., 1988; Gasparin et al., 2013). 
The pots containing the rhizophores were placed into incubator chambers, of B.O.D. type under controlled temperature of $20 \pm 2{ }^{\circ} \mathrm{C}$ and $24 \mathrm{~h}$ of photoperiod.

The pots went through a rotation of positions inside the chamber weekly. Daily irrigations were performed to keep the sand humidity in homogeneous levels (similar to field capacity), standardizing the level of water in all the pots by weight (1.3 kg in each pot).

\section{Traits evaluated}

The performance of yacon plantlets under different aluminum concentrations was evaluated by means of plantlet emergence and initial growth. The emergence of the plantlets was evaluated by daily monitoring the pots and determining the emergence time and speed index.

After 38 days, the initial growth of yacon plantlets was evaluated considering the number of leaves, shoot height, leaf area, radicle length, and accumulated biomass. The leaf area was obtained in a leaf area integrator (Area meter LI 3100, Li-cor) and the biomass of leaves, stems, and radicles were obtained by drying the plant part in convection oven at $60{ }^{\circ} \mathrm{C}$ (STF SP-102/2000 CIR), until constant weight, which was determined in a precision electronic scale (precision: $0.001 \mathrm{~g}$ ). All measurements were performed in three plantlets per experimental plot and the value of the plot was expressed as mean of the three plantlets.

\section{Data analyses}

The normality of residues was tested by the ShapiroWilk test and the data were subjected to analyses of variance. The quantitative variables were studied by regression analyses $(\mathrm{p} \leq 0.05)$, and the models were chosen based on their significance, magnitude, and significance of the regression coefficients. The statistical program used for the data analysis was R, version 2.15.3 (R Core Team, 2013).

\section{RESULTS}

\section{Aluminum toxicity}

The analyses of variance revealed significant differences $(p \leq 0.01)$ for all variables as a function of the aluminum content in the substrate, and the dependent variables fit linear regression models (Table 1) with coefficients of determination $\left(\mathrm{R}^{2}\right)$ above $80 \%$ in most cases. This fact led to the conclusion that linear regression equations of first degree were mathematically adequate to describe the functional relationship between aluminum contents and initial growth of yacon plantlets.

Among the six aluminum contents in the substrate, two of them were lethal to the yacon plantlets, inhibiting rhizophore development and restraining the radicle and shoot growth. The plantlets were unable to germinate in concentrations above $100 \mathrm{mg} \mathrm{L}^{-1}$; therefore, the quantification of damage that followed only considered the linear limitation caused from 0 to $100 \mathrm{mg} \mathrm{L}^{-1}$.

The limitation caused by the presence of aluminum in the substrate was visible on the growth of both shoots and radicles, restricting their growth and, thus, the development of the plantlets as a whole. Figure 1 shows the visual effects of the aluminum content on the development of the plantlets, 38 days after the rhizophores had been subjected to the treatments.

\section{Effect on emergence}

The emergence time and speed index of yacon plantlets were linearly limited by exposure to increasing aluminum concentrations. The mean time required for the plantlets to break through the surface of the substrate increased between levels of 0 and $50 \mathrm{mg} \mathrm{L}^{-1}$ (Figure 2A), with a consequent decrease in the emergence speed index (Figure $2 \mathrm{~B}$ ). At $100 \mathrm{mg} \mathrm{L}^{-1}$ of aluminum, the plantlets were unable to emerge.

\section{Effect on the initial growth}

Plantlet length was limited, either above or below the substrate surface, by the presence of aluminum (Figure $3 \mathrm{~A}$ and $3 \mathrm{~B}$ ). The increase in the content of aluminum in the substrate caused linear decrease of the radicle length, limiting its capacity to absorb water and nutrients from the substrate and, consequently, inhibiting the development of the shoots.

Even when the plantlets were able to start emitting shoots, resulting in the emergence of small leaves and stems with low vigor, at $50 \mathrm{mg} \mathrm{L}^{-1}$ of aluminum, these plantlets were not able to develop proper root systems. These data show that aluminum content above this level is already enough to inhibit the radicle growth in yacon plantlets (under the evaluated conditions), and the initial growth of the shoots only occurred due to the use of remaining reserves from the rhizophores.

At the content of $50 \mathrm{mg} \mathrm{L}^{-1}$ aluminum, plantlet height was already decreased in $50 \%$ (Figure $3 \mathrm{~A}$ ), while root development was completely discontinued. At $25 \mathrm{mg} \mathrm{L}^{-1}$, aluminum was already causing losses of approximately $30 \%$ in radicle length (Figure $3 \mathrm{~B}$ ).

The foliage suffered severe losses due to the presence of higher contents of aluminum in the substrate (Figure $3 \mathrm{C}$ and 3D). At $50 \mathrm{mg} \mathrm{L}^{-1}$, the number of leaves was already reduced to the half, as compared with number of leaves of plantlets grown in the absence of aluminum. For leaf area, this decrease was similar but severer, presenting a total decrease of about $57 \%$ as compared with the control, which means a loss of approximately $1 \mathrm{~cm}^{2}$ of leaf area for each $1.39 \mathrm{mg} \mathrm{L}^{-1}$ of aluminum initially present in the substrate. 
Table 1: Summary of regression analysis: emergence time (ET), emergence speed index (SI), shoot height (SH), radicle length (RL), leaf number (LN), leaf area (LA), leaf biomass (LB), stem (SB), and radicles (RB) of yacon plantlets subjected to different aluminum contents in the substrate

\begin{tabular}{lccccccccc}
\hline \multirow{2}{*}{ Model } & \multicolumn{10}{c}{ Pr $>$ F } \\
\cline { 2 - 11 } & ET & SI & SH & RL & LN & LA & LB & SB & RB \\
\hline Linear & 0.00 & $0.02^{* *}$ & $0.00^{*}$ & $0.00^{*}$ & $0.00^{*}$ & $0.00^{*}$ & $0.00^{*}$ & $0.03^{* *}$ & $0.00^{*}$ \\
Quadratic & $0.01^{*}$ & $0.35^{\text {ns }}$ & $0.44^{\text {ns }}$ & $0.01^{*}$ & $0.47^{\text {ns }}$ & $0.00^{*}$ & $0.02^{* *}$ & $0.63^{\text {ns }}$ & $0.00^{*}$ \\
Cubic & $0.22^{\text {ns }}$ & $0.07^{\text {ns }}$ & $0.16^{\text {ns }}$ & $0.00^{*}$ & $0.14^{\text {ns }}$ & $0.00^{*}$ & $0.00^{*}$ & $0.11^{\text {ns }}$ & $0.02^{* *}$ \\
\hline /CV $(\%) /$ & 5.6 & 27.1 & 18.2 & 18.1 & 15.5 & 9.7 & 12.3 & 26.1 & 13.7 \\
\hline
\end{tabular}

ns - not significant; CV - coefficient of variation.

* Significant at $1 \%$;* Significant at $5 \%$ probability, by the $\mathrm{F}$ test.

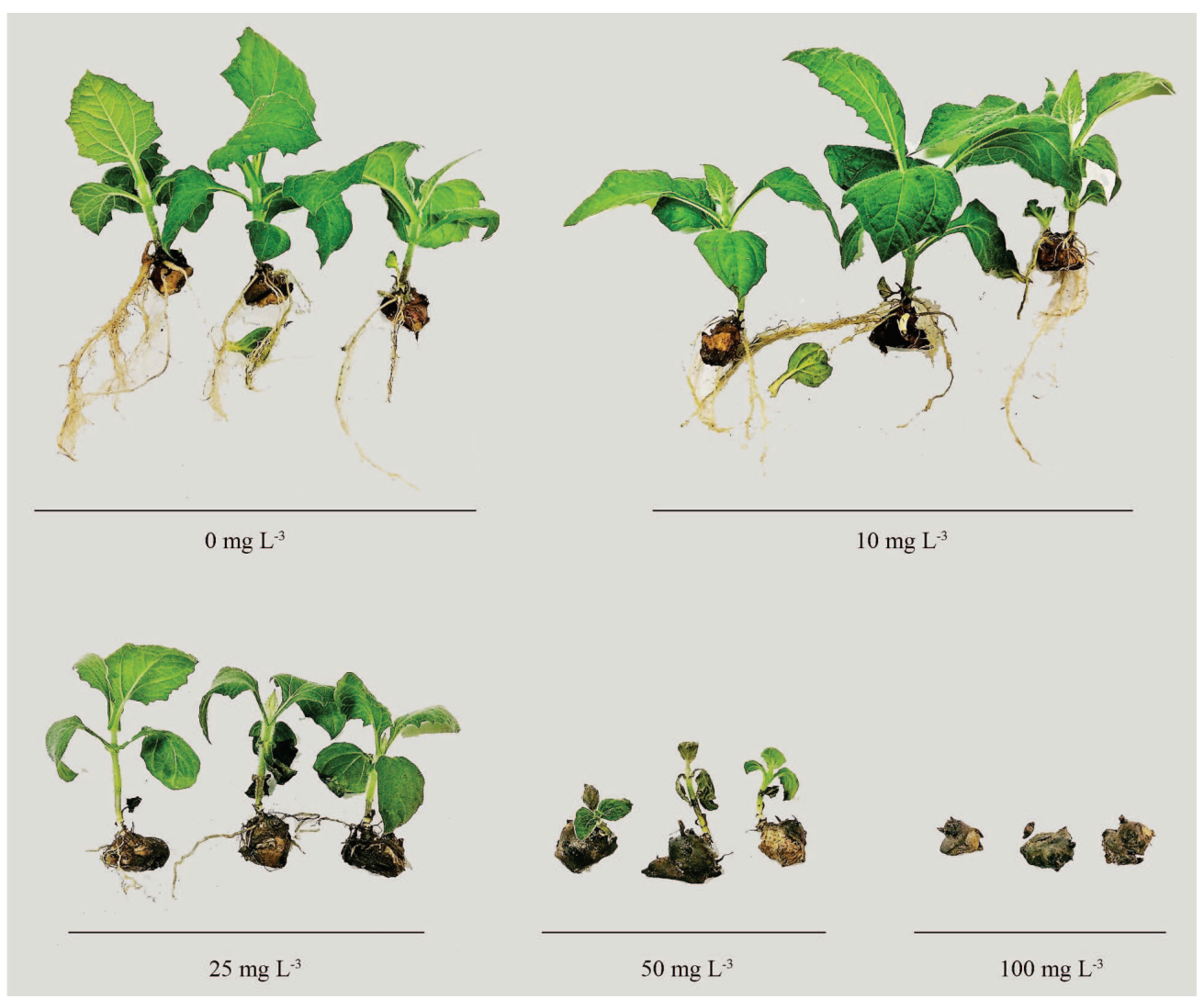

Figure 1: Yacon plantlets grown under different substrate aluminum contents, at 38 days of growth in a controlled environment.
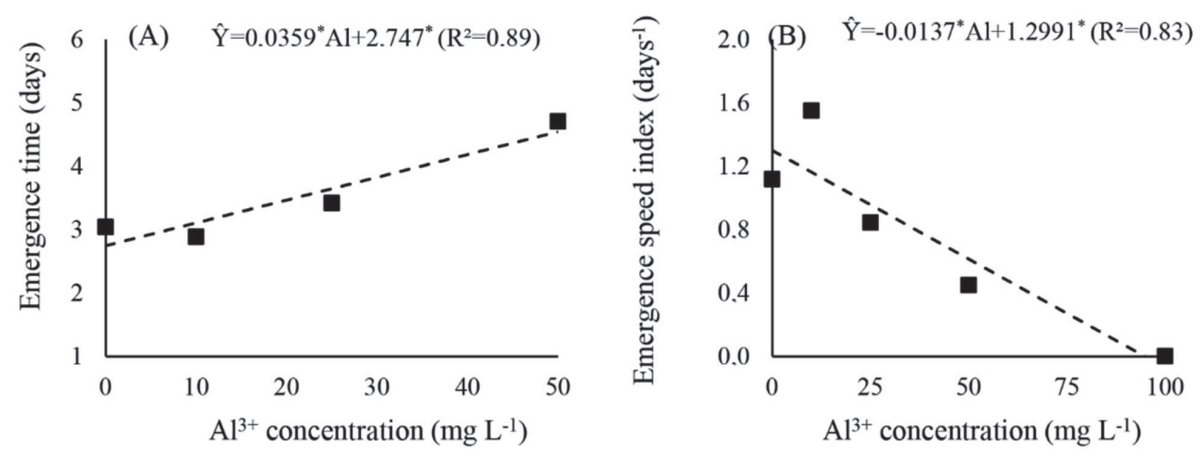

${ }^{*}$ Significant by the t-test at $5 \%$ probability.

Figure 2: Regressions for emergence time (A) and emergence speed index (B) of yacon plantlets subjected to different concentrations of aluminum in sand substrate, in controlled environment. 


\section{Effect on biomass accumulation}

Aluminum caused linear losses in biomass accumulation of leaves, stems, and radicles of yacon (Figures $4 \mathrm{~A}, 4 \mathrm{~B}$, and $4 \mathrm{C}$ ), corroborating the results of root growth described previously; a more drastic limitation was observed in radicle biomass, with a $30 \%$ decrease at the $25 \mathrm{mg} \mathrm{L}^{-1}$ level of aluminum, and no considerable biomass above $50 \mathrm{mg} \mathrm{L}^{-1}$. Losses of 55 and $50 \%$ were observed in leaf and stem biomasses, respectively, when the aluminum content approached $50 \mathrm{mg} \mathrm{L}^{-1}$.

\section{DISCUSSION}

It is worth highlighting that yacon plantlets were able to express a peak of growth when exposed to lower aluminum contents (around $10 \mathrm{mg} \mathrm{L}^{-1}$ ), with a slight boost in leaf area, emergence speed index, and biomass accumulation. Although this deviation was not enough to make data fit to another regression model in the present study, this is worth mentioning since it is similar to the behavior of several other species. Veloso et al. (1995), studying black pepper, observed this positive effect for leaf biomass caused by aluminum in concentrations up to $15 \mathrm{mg} \mathrm{L}^{-1}$. This was also described by Salvador et al. (2000), in guava seedlings, with positive effects on plant height and leaf area at concentrations below $10 \mathrm{mg} \mathrm{L}^{-1}$.

The explanation for that fact is that, even though aluminum is not considered an essential element for
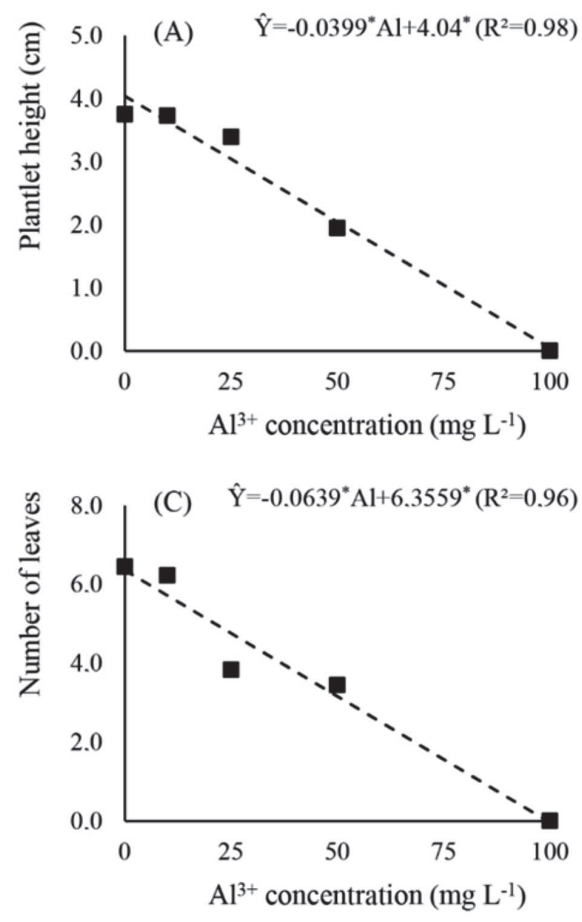

* Significant by the t-test at $5 \%$ probability.

Figure 3: Regressions for plantlet height (A), radicle length (B), number of leaves (C), and leaf area (D) of yacon plantlets submitted to different concentrations of aluminum in sand substrate, in a controlled environment.

Rev. Ceres, Viçosa, v. 65, n.2, p. 120-126, mar/abr, 2018 plants, low concentrations can stimulate the growth of some plant species (Ferreira et al., 2006). The beneficial effect of small amounts of aluminum may be related to the fact that the acidity caused by aluminum results in an increase in the solubility and availability of iron (Foy, 1992). Therefore, small amounts of aluminum may help in the correction or prevention of internal iron deficiency. By displacing this element from sites where it is metabolically inactive, aluminum may also block negative charges of the cell wall, enhancing phosphorus absorption (Mullette et al., 1974).

The results of this study show the existence of a negative effect of aluminum in the substrate on the development of yacon plantlets. Aluminum causes changes in the cell membrane and can cause exudation of cell contents (Macedo et al., 2008). According to Marcos Filho (2005), some constituents of these cell exudates are necessary for the maintenance of the internal osmotic potential, cellular turgor, and normality of water intake; the release of these exudates into the environment may also enhance the development of microorganisms that hinder germination.

The toxic effect of aluminum on the initial growth of yacon was clear, causing losses in the growth of both radicles and shoots. The limitation was especially severe in the development of radicles.

The decrease in shoot development due to aluminum toxicity occurs as result of the drop in the photosynthetic
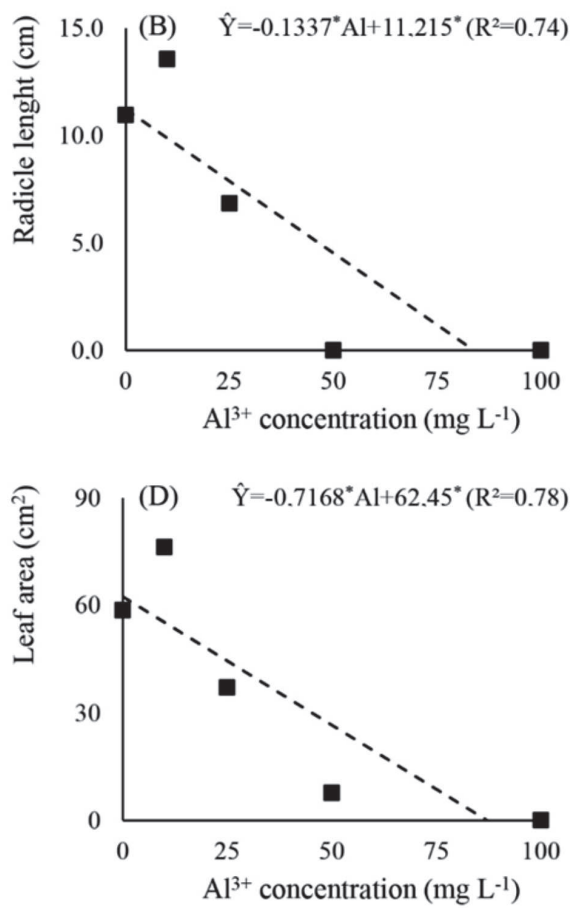

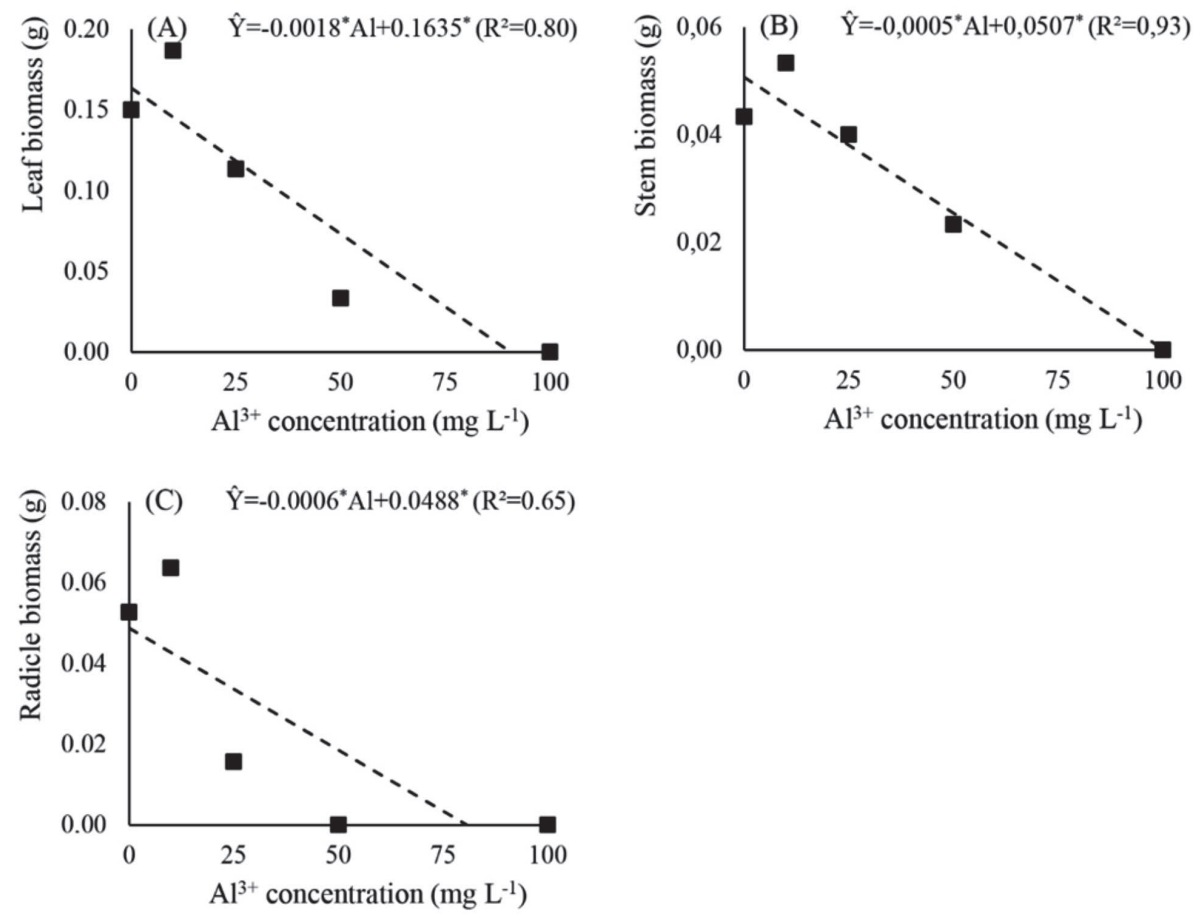

"Significant by the t-test at $5 \%$ probability.

Figure 4: Regressions for leaf biomass (A), stem biomass (B), and radicle biomass (C) of yacon plantlets submitted to different concentrations of aluminum in sand substrate, in controlled environment.

activity. Konrad et al. (2005) described that aluminum limits the formation and function of chloroplasts by damaging the thylakoid membranes and the electron transport chain, directly repressing $\mathrm{CO}_{2}$ assimilation rate of several species.

Aluminum toxicity also causes injuries to cell structures, such as the nucleus, cytoskeleton, plasma membrane, and cell wall, impairing cell division and expansion, which consequently result in restricted growth and poor foliage (Hartwig et al., 2007). According to Pereira et al. (2006), $\mathrm{Al}^{3+}$ also causes oxidative damage by the inhibition of aminolaevulinic acid dehydratase, which plays an important role in the synthesis of chlorophyll. Therefore, higher concentrations of this ion may result in lower chlorophyll content, which leads to limitation of plant metabolic potential.

Aluminum phytotoxic effect causing significant losses in radicle growth has also been observed during the propagation of potato (Tabaldi et al., 2007). This has also been reported in plants propagated by botanical seeds, as observed by Santos et al. (2010), working with arugula plants, and by Colodetti et al. (2012), working with seedlings of different cucumber cultivars, which highlighted linear decrease in root length as aluminum concentration in the environment increased.

Besides the losses previously mentioned, it was also possible to observe the darkening of radicles (Figure 1), a characteristic symptom of aluminum toxicity (Macedo et al., 2011). The restricted development of both shoots and radicle during emergence and initial growth of yacon plantlets will restrict their entire life cycle, since the plant will have reduced capacity to explore the soil, making it difficult to absorb water and nutrients and compromising metabolism and growth of the whole plant, generating severe consequences for the crop productivity (Lima et al., 2007).

\section{CONCLUSION}

The presence of aluminum in the substrate negatively influences the emergence and initial growth of yacon, causing losses in foliage, biomass accumulation, growth, and especially restricting radicle development.

Aluminum toxicity fully inhibits radicle growth in contents above $83 \mathrm{mg} \mathrm{L}^{-1}$ (estimate by radicle biomass equation), under the controlled conditions used in this experiment.

\section{ACKNOWLEDGEMENT}

Authors thank the Conselho Nacional de Desenvolvimento Científico e Tecnológico (CNPq) and the Fundação de Amparo à Pesquisa e Inovação do Espírito Santo (FAPES), for financial support, and FAPES, for the second author's research grant. 


\section{REFERENCES}

Albuquerque EN \& Rolim PM (2012) Potencialidades do yacon (Smallanthus sonchifolius) no diabetes Mellitus. Revista de Ciências Médicas, 20:03-04.

Asp FL, Bengtsson B \& Jensen P (1988) Growth and cation uptake in spruce (Picea abies Karst.) grown in sand culture with various aluminium contents. Plant and Soil, 111:127-133.

Campos D, Betalleluz-Pallardel I, Chirinos R, Aguilar-Galvez A, Noratto, G \& Pedreschi R (2012) Prebiotic effects of yacon (Smallanthus sonchifolius) a source of fructo-oligosaccharides and phenolic compounds with antioxidant activity. Food Chemistry, 135:1592-1599.

Cardoso ISMH (2008) Raiz tuberosa de yacon (Smallanthus sonchifolius): potencialidade de cultivo, aspectos tecnológicos e nutricionais. Ciência Rural, 38:898-905.

Chandran D, Sharopova N, VandenBosch KA, Garvin DF \& Samac DA (2008) Physiological and molecular characterization of aluminum resistance in Medicago truncatula. BMC Plant Biology, 8:1-17.

Colodetti TV, Rodrigues WN, Oliveira FL, Martins LD \& Tomaz MA (2012) Efeito do alumínio na germinação e na morfologia radicular de cultivares de pepino. Enciclopédia Biosfera, 8:767776 .

Ferreira RP, Moreira A \& Rassini JB (2006) Toxidez de alumínio em culturas anuais. São Carlos, Embrapa Pecuária Sudeste. 34p. (Documentos, 63).

Freitas FA, Kopp MM, Sousa RO, Zimmer PD, Carvalho FIF \& Oliveira AC (2006) Absorção de P, Mg, Ca e K e tolerância de genótipos de arroz submetidos a estresse por alumínio em sistemas hidropônicos. Ciência Rural, 36:72-79.

Foy CD (1992) Soil chemical factors limiting plant root growth In: Hatfield JL \& Stewart BA (Eds.) Limitations to plant root growth. New York, Springer. p. 97-149.

Gasparin E, Araujo MM, Tolfo CV, Foltz DRB \& Magistrali PR (2013) Substrates for germination and physiological quality of storage seeds of Parapiptadenia rigida (Benth.) Brenan. Journal of Seed Science, 35:77-85.

Genta S, Cabrera W, Habib N, Pons J, Carillo IM, Grau A \& Sánchez S (2009) Yacon syrup: beneficial effects on obesity and insulin resistance in humans. Clinical Nutrition, 28:182-187.

Gusso AP, Mattanna P \& Richards N (2015) Yacon: benefícios à saúde e aplicações tecnológicas. Ciência Rural, 45:912-919.

Habib NC, Serra-Barcellona C, Honoré SM, Genta SB \& Sánchez SS (2015) Yacon roots (Smallanthus sonchifolius) improve oxidative stress in diabetic rats. Pharmaceutical biology, 53:1183-1193.

Hartwig I, Oliveira AC, Carvalho FIF, Bertan I, Silva JAG, Schmidt DAM \& Reis CES (2007) Mecanismos associados à tolerância ao alumínio em plantas. Semina: Ciências Agrárias, 28:219-228.

Hoagland DR \& Arnon DL (1950) The water culture methods for growing plants without soil. Berkeley, California Agriculture Experiment Station. 32p.

Kollmeier M, Felle HH \& Horst WJ (2000) Genotypical differences in aluminum resistance of maize are expressed in the distal part of the transition zone. Is reduced basipetal auxin flow involved in inhibition of root elongation by aluminum? Plant Physiology, 122:945-956.

Konrad MLF, Silva JAB, Furlani PR \& Machado EC (2005) Trocas gasosas e fluorescência da clorofila em seis cultivares de cafeeiro sob estresse de alumínio. Bragantia, 64:339-347.
Lima RDLS, Severino LS, Ferreira GB \& Beltrão M (2007) Crescimento da mamoneira em solo com alto teor de alumínio na presença e ausência de matéria orgânica. Revista Brasileira de Oleaginosas e Fibrosas, 11:15-21.

Macedo CMDP, Lopes JC, Amaral JAT \& Fonseca AFA (2008) Germinação e vigor de sementes de café submetidas ao estresse com alumínio. Scientia Agraria, 9:235-239.

Macedo FL, Pedra WN, Silva SA, Vasconcellos Barreto MC \& Silva-Mann R (2011) Efeito do alumínio em plantas de pinhãomanso (Jatropha curcas L.), cultivadas em solução nutritiva. Semina: Ciências Agrárias, 32:157-164.

Marcos Filho JMF (2005) Fisiologia de sementes de plantas cultivadas. Piracicaba, Fealq. 465p.

Marin A, Santos DMMD, Banzatto DA \& Ferraudo AS (2004) Germinação de sementes de guandu sob efeito da disponibilidade hídrica e de doses subletais de alumínio. Bragantia, 63:13-24.

Moura NA, Caetano BF, Sivieri K, Urbano LH, Cabello C, Rodrigues MA \& Barbisan LF (2012) Protective effects of yacon (Smallanthus sonchifolius) intake on experimental colon carcinogenesis. Food and Chemical Toxicology, 50:2902-2910.

Mullette KJ, Hannon NJ \& Elliott AGL (1974) Insoluble phosphorus usage by Eucalyptus. Plant and Soil, 41:199-205.

Ojansivu I, Ferreira CL \& Salminen S (2011) Yacon, a new source of prebiotic oligosaccharides with a history of safe use. Trends in Food Science \& Technology, 22:40-46.

Oliveira GO, Braga CP \& Fernandes AAH (2013) Improvement of biochemical parameters in type 1 diabetic rats after the roots aqueous extract of yacon (Smallanthus sonchifolius). Food and Chemical Toxicology, 59:256-260.

Pereira LB, Tabaldi LA, Gonçalves JF, Jucoski GO, Pauletto MM, Weis SN \& Schetinger MRC (2006) Effect of aluminum on äaminolevulinic acid dehydratase (ALA-D) and the development of cucumber (Cucumis sativus). Environmental and Experimental Botany, 57:106-115.

Salvador JO, Moreira A, Malavolta E \& Cabral CP (2000) Influência do alumínio no crescimento e na acumulação de nutrientes em mudas de goiabeira. Revista Brasileira de Ciência do Solo, 24:787-796.

Santos CD, Almeida JD, Santos AD, Vieira E \& Peixoto C (2010) Rúcula em cultivo hidropônico submetida a diferentes concentrações de alumínio. Bioscience Journal, 26:905-912.

Silva JAG, Reis CES, Crestani M, Sousa RO, Oliveira AC \& de Carvalho FIF (2013) Absorção de cálcio e magnésio por cultivares de aveia submetidas a níveis de toxidez por alumínio. Semina: Ciências Agrárias, 34:3563-3576.

Tabaldi LA, Nicoloso FT, Castro GY, Cargnelutti D, Gonçalves JF, Rauber R \& Bisognin DA (2007) Physiological and oxidative stress responses of four potato clones to aluminum in nutrient solution. Brazilian Journal of Plant Physiology, 19:211-222.

R Development Core Team (2013) R: A Language and environment for statistical computing. Disponível em: <https://www.rproject.org/>. Acessado em: 04 de maio de 2016.

Vaz-Tostes MG, Viana ML, Grancieri M, dos Santos Luz TC, de Paula H, Pedrosa RG \& Costa NMB (2014) Yacon effects in immune response and nutritional status of iron and zinc in preschool children. Nutrition, 30:666-672.

Veloso CAC, Muraoka T, Malavolta E \& Carvalho JD (1995) Efeitos do alumínio em pimenteiras do reino (Piper nigrum L.) cultivadas em solução nutritiva. Scientia Agricola, 52:368-375. 